\title{
A VIRTUAL ORGANISATION MODEL FOR E-GOVERNMENT
}

\author{
Janice Bum and Greg Robins \\ Edith Cowan University \\ Perth, W.A. Australia \\ e-mail: j.bum@alecu.edu.au
}

\begin{abstract}
This paper looks at the implementation of a new customer value alliance model in e-government. Firstly we review the issues of e-government and the drive towards customer centric organisations in the context of multiple government agencies. A model of e-Govemment is introduced and examined within the context of a virtual organisation model which can be applied along the customer value chain across multiple service agencies. A case study is used to demonstrate how this concept of a virtual organisation as a customer value-alliance model can effect a successful transition to e-Govemment from a traditional Government model. Finally, we examine how the Aboriginal Affairs Department, a Western Australian Government agency is implementing this model for improved customer service and the implications of this model for the management of change in a developing e-community
\end{abstract}

\section{INTRODUCTION}

It is now well accepted that with the emergence of the World Wide Web, a totally new business environment, ebusiness, has evolved where companies must work together to create online networks of customers, suppliers and value-added processes (Ticoll, Lowry and Kalakota, 1998; El Sawy et al. 1999). Such radical transformations are not solely restricted to the business world but are now impacting on the public sector where the latest "e"volution is e-Government (Stratford and Stratford, 2000). Within the next five years the Internet will transform not only the way in which most public services are delivered but also the fundamental relationship between government and citizen (Von Hoffman, 1999, Sprecher, 2000, Zulfikar et al, 2001). With few exceptions, however, governments have arrived late on the scene. As monopoly suppliers, none were worried about being "Amazoned" by a new web-based competitor. Transactions with government are rarely a matter of choice and government employees are unlikely to be rewarded for devising innovative web based strategies to replace them in their jobs. Nevertheless the drive is now on for radical government change (Morin, 1999; Sprecher, 2000). A major driver has been the desire to reduce costs and make revenues go further. Savings of $20 \%$ are not unusual in the e-business community as they network their supply chains (Burn and Hackney, 2000 ), and such concepts transfer easily into government services. U.S. federal, state and local procurement spending on materials and services in 2000 was estimated at around $\$ 550$ billion, and in the European Union member states' combined procurement spending was around $\$ 778$ billion (Symonds, 2000). With a $20 \%$ cut in costs we are looking at savings of around $\$ 250$ billion.

An additional driver comes from customer expectations. Customers now have far greater access to information and demand personalised experiences as opposed to simply acquiring goods and services. A customer driven organisation is one that maintains a focus on the needs and expectations of customers both spoken and unspoken in the creation and/or improvement of the product or service provided. Successful organisations, state or municipal governments and federal government departments and agencies have recognised that developing customer focus is an absolute necessity (Cavanagh and Livingston 1997; Schoeniger, 2000).

One of the proposed solutions has been the creation of government portals such as the Singapore or UK portals. These have been designed around "life events" such as changes in marital status and allow users to find what they are looking for by using "How do I - - ?" type questions rather than by forcing the client to search through complex organisational structures possibly linking up to 50 different departments in one search. In reality the government portal acts as a virtual organisation front interacting with customer driven demand. This type of solution requires major changes within and without the government organisation and as yet, there is no clear evidence of success. (Jellinek, 2000; Traunmuller, 2001). The failure of a massive government IT outsourcing project in Australia in 2001, has highlighted the enormous difficulties of implementing cross-agency collaboration. The proposed solution is to return autonomy to the individual government agencies but to focus on the development of inter-agency systems based on customer services and added customer value.

This paper looks at a specific e-government solution in the context of the West Australian (W.A.) Government. Firstly we review the issues of customer focus and utilising extemal organisations in the context of government agencies. Ostensibly government agencies are service driven organisations with a major goal of providing a service to the public. We then discuss how traditional Govemment organisations are set up with a focus on W.A. and how the concept of a value alliance network can improve customer service. Finally, we examine how the Aboriginal Affairs Department, a W.A. Government agency is implementing a value-alliance model as a virtual organisation and the implications of this model for the management of change. 


\section{DEVELOPING A CUSTOMER FOCUS}

Prahalad and Ramaswamy (2000) suggest that organisations need to "create their future by hamessing competence in an enhanced network that includes customers". As a minimum they propose four fundamental realities which managers must come to grips with:

- They have to engage their customers in an active, explicit, and ongoing dialogue;

- They have to mobilise communities of customers;

- They have to manage customer diversity; and

- They have to engage customers in co-creating personalised experiences.

They developed a three-stage model which we have adapted to a government context and summarised below in Table 1.

\begin{tabular}{|c|c|c|c|}
\hline & The Agency & $\begin{array}{l}\text { Network of } \\
\text { Agencies } \\
\text { B2B }\end{array}$ & $\begin{array}{l}\text { Enhanced Value Network } \\
\text { e-Government }\end{array}$ \\
\hline $\begin{array}{l}\text { Unit of } \\
\text { analysis }\end{array}$ & $\begin{array}{l}\text { The government } \\
\text { agency }\end{array}$ & $\begin{array}{l}\text { The extended } \\
\text { enterprise:- the } \\
\text { agency, its agency } \\
\text { partners and other } \\
\text { service providers }\end{array}$ & $\begin{array}{l}\text { The value alliance:- the agency, } \\
\text { its partners, other funding and } \\
\text { service providers and its } \\
\text { customers }\end{array}$ \\
\hline Resources & $\begin{array}{l}\text { What is available } \\
\text { within the agency }\end{array}$ & $\begin{array}{l}\text { Access to other } \\
\text { agencies' } \\
\text { competencies and } \\
\text { funding }\end{array}$ & $\begin{array}{l}\text { Access to other agencies' } \\
\text { competencies and funding, as well } \\
\text { as customers' competencies and } \\
\text { investments of time/ effort }\end{array}$ \\
\hline $\begin{array}{l}\text { Basis for } \\
\text { access to } \\
\text { competence }\end{array}$ & $\begin{array}{l}\text { Internal agency- } \\
\text { specific processes }\end{array}$ & $\begin{array}{l}\text { Privileged access to } \\
\text { agencies within the } \\
\text { network }\end{array}$ & $\begin{array}{l}\text { Infrastructure for active ongoing } \\
\text { dialogue with diverse customers }\end{array}$ \\
\hline $\begin{array}{l}\text { Added } \\
\text { Value of } \\
\text { managers }\end{array}$ & $\begin{array}{l}\text { Nurture and build } \\
\text { competencies }\end{array}$ & $\begin{array}{l}\text { Manage } \\
\text { collaborative } \\
\text { partnerships } \\
\end{array}$ & $\begin{array}{l}\text { Harness customer competence, } \\
\text { manage personalised experiences, } \\
\text { and shape customer expectations }\end{array}$ \\
\hline $\begin{array}{l}\text { Value } \\
\text { creation }\end{array}$ & Autonomous & $\begin{array}{l}\text { Collaborate with } \\
\text { partner agencies }\end{array}$ & $\begin{array}{l}\text { Collaborate with partner agencies } \\
\text { and with active customers }\end{array}$ \\
\hline $\begin{array}{l}\text { Sources of } \\
\text { managerial } \\
\text { tension }\end{array}$ & $\begin{array}{l}\text { Service-unit } \\
\text { autonomy vs } \\
\text { leveraging core } \\
\text { competencies }\end{array}$ & $\begin{array}{l}\text { Partner is both } \\
\text { collaborator and } \\
\text { competitor for } \\
\text { value }\end{array}$ & $\begin{array}{l}\text { Customer is both collaborator and } \\
\text { competitor for value }\end{array}$ \\
\hline
\end{tabular}

Table 1: Developing Model of e-Government

Table 1 shows that the idea of extending the government services network and changing the nature of its usage to improve core competencies is a central component of this model. In the past, most government agencies had a traditional focus where they have embraced the concept of the extended enterprise but have been primarily concerned with alliances, networks, and collaborations among other agencies and services. The old idea of the "extended enterprise" should give way to the idea of an enhanced network of traditional agencies, other services, funding bodies and most importantly, customers. Government managers need to recognise that consumers are a source of competencies. They must focus on developing relationships with the customer as the agent that is most dramatically transforming government as we know it and leading the e-government and governance revolution (Stamoulis et al, 2001).

\section{TRADITIONAL SITUATION}

Organisations, particularly Government organisations are typically structured in a top down bureaucratic style, creating a barrier between the customer and the organisation and forcing customers to develop a knowledge of the structure to be able to seek services (Barreyre, 1988). The Western Australian Government has established 53 agencies to provide a variety of Government services to the public. Each agency reports to a Cabinet Minister, has a Chief Executive Officer accountable for all aspects of the agency and a corporate executive team responsible for the operation of the divisions within the agency. Each agency is charged with a specific function or service and has responsibility for setting Policy in relation to their function, providing the Minister with responses to correspondence and assisting the public. As an example the Aboriginal Affairs Department has responsibility for assisting all Aboriginal people within the state to access Government services; ensuring the 
welfare of Aboriginal people, their culture and heritage and maintaining traditional Aboriginal sites. The Ministry of Sport and Recreation are responsible for increasing the participation of all West Australians in sport, maintaining sporting venues throughout the state and assisting elite West Australian athletes. The Education Department is responsible for the education of all primary and secondary aged children in the state. All Western Australian Government agencies have had similar structures that comply to a traditional organisational structure and for the main part work in isolation from each other. Both the Education Department and Ministry of Sport and Recreation have an Aboriginal affairs section which work in isolation of each other and the Aboriginal Affairs Department.

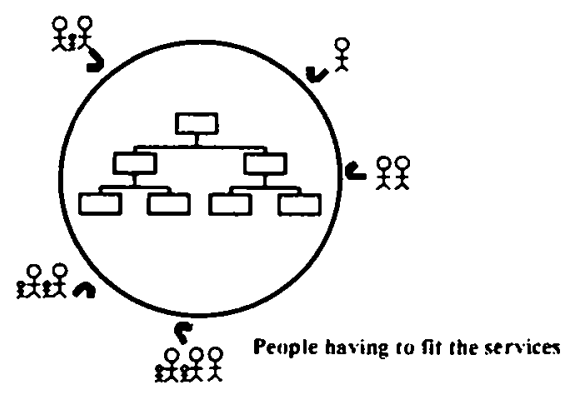

Figure 1 - Traditional Agency

This approach forces the customers to fit or break into this structure if they require a service (figure 1). Customers must seek out the area that deals with their particular requirement. They must move between many different Agencies to gain access to all the services they need. As an example a company within Western Australia seeking to explore mineral deposits on Aboriginal Lands would need to seek approval and apply for appropriate permits through the Department of Minerals and Energy, the Department of Land Administration and the Aboriginal Affairs Department. This requires the customer to discover which Departments need to be approached, to approach each individually and to locate the appropriate section within each of these to obtain the correct advice.

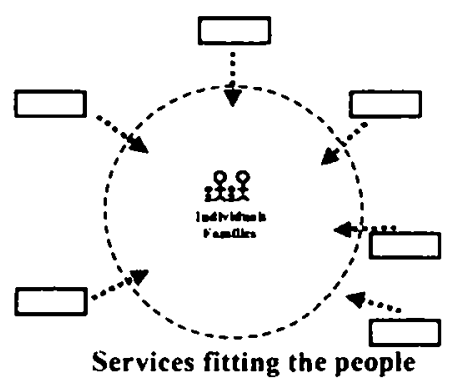

Figure 2. New Agency

There is a need particularly within a service environment such as Government agencies to move the customer into the centre and to offer a wide range of services across agencies (Hopkins and Jamil, 1997). This requires agencies to develop close working relationships and implement a structure based on the idea of collaboration. (Figure 2).

\section{ACHIEVING A SERVICE DRIVEN ENVIRONMENT}

Many companies already focus on core value adding processes, working with external partners to jointly bring forward a service. These companies believe that a more flexible organisation built around a series of alliances and business relationships, is the most effective way to respond quickly and creatively to constantly changing 
market conditions (Miles and Snow, 1995). The conventional, vertically integrated corporation may be too slow, or have too much retained infrastructure to allow it to compete with companies who can quickly put together a customised response to its clients (Campbell and DiNicola 1997). If Government agencies are to provide a public service then they must embrace wholeheartedly the notion of the value alliance. The value alliance emphasises the decentralisation of control, the creation of more flexible patterns of working, a greater empowerment of the workforce and the customer, the displacement of hierarchy by teamwork, the development of a greater sense of collective responsibility and the creation of more collaborative relationships among co-workers and customers.

To initiate such developments an agency needs to perform a full customer value chain analysis in order to set up a number of different agency alliances through an electronic network. This may form the basis for a one-stop portal where the alliance combines a range of services and facilities in one package forming one single customer supply chain. Participants may come together on a project by project basis but generally the general contracting agency provides coordination. Where longer term relationships have developed the value alliance often adopts the form of value constellations where agencies and funding services have multiple interactions and a complex and enduring communications structure is embedded within the alliance (Burn and Barnett, 2000). Substitutability has traditionally been a function of efficiency and transaction costs: searching for, evaluating, and commencing operations with potential partners has been a costly and slow government procedure, relying as it does on information transfer, the establishment of trust and policy rules across states, time zones, culture, and legal frameworks. These have determined the relative positioning of partners on the chain and the reciprocity of the relationship.

This value-alliance will be built around customer value chains and enable the sharing of resources, skills and knowledge to produce a 'best' customer solution and enable agencies to be more responsive to customer requirements and offer superior quality of service. Each agency may be required to form several value-alliance virtual organisations depending on what has been identified as the requirements for one stop processes for clients.

\section{MANAGING A VIRTUAL AGENCY MODEL}

In order to achieve a successful value-alliance it is essential that a business planning model is established that ensures each member agency has 'buy-in' to the desired outcomes. The first step to achieve 'buy-in' is to establish a high level committee comprising of the Chief Executive Officers from each of the member agencies. The committee is charged with the responsibility of identifying the virtual organisation's goals. These goals must then be meshed into the individual agency's processes. Any business planning must be built on services, delivery goals and objectives that focus on its customers through direct customer and front-line employee input. To achieve this there must be a fundamental shift in management and workforce thinking and practices that include:

- Pervasive knowledge sharing, feedback and communication;

- Integration of environmental considerations at the earliest stages of design;

- Effective partnerships with customers.

- Commitment to using customer feedback to drive changes in operations, goals and vision; and

- Frontline employees given the authority to deal with customer issues.

It is essential that each agency is represented by the Chief Executive Officer. Commitment grows as employees understand what is being developed, this understanding is achieved through communication and commitment from the top. In order to achieve the most appropriate goals that focus on the customers' requirements and establish a one stop shop from the clients viewpoint a model must be established that passes information between all levels both within each agency and between the agencies. It is important to recognise the customers as integral members of the virtual organisation Glassey, 2001).

This model establishes information flows that:

- Ensure customers and front line staff can impact on the strategic planning process through passing information upwards;

- Agreed goals are passed to all levels of each agency;

- These goals are articulated to clients; and

- Planning takes place across agencies at all levels

A key to the success of an organisation is a network of open communication, a combination of sharing and listening flowing both horizontally and vertically through the organisation. Management must share details with employees. A workforce that is involved is much more likely to 'buy in' to management's vision and work together for results. Management must be able to combine the differences in diversity and organisation structure, in order to make the virtual organisation reach its target. Virtual teamwork places a particular emphasis 
on communication and the development of 'awareness' skills. It is critical that front-line employees have immediate access to current information.

The key groups in this model are the Strategic Planning Committee (SPC) and the local staff. Key responsibilities of the SPC are to develop goals that reflect customer needs, all members are committed to the goals and each member ensures that their agency implements processes aimed at addressing the goals. Local staff have two key responsibilities:

1. Ascertain needs and provide information, advice and advocacy support to groups, communities and individuals within their area; and

2. Inform government of unmet needs and priority issues

\section{CASE STUDY - THE ABORIGINAL AFFAIRS DEPARTMENT (AAD)}

\section{AAD Organisation}

The Aboriginal Affairs Department (AAD) is a W. A. State Government Agency. In 1994 a taskforce on Aboriginal Social Justice was formed. The terms of reference for this taskforce was to review the activities of the Government of Western Australia in relation to the social conditions and development of Aboriginal people and to recommend a strategy for implementation of Government's programmes. Recommendations of the taskforce included:

- The need for high calibre regional coordinators with a role to include breaking down barriers between Government agencies and reducing waste and duplication;

- A regional structure be implemented to undertake regional liaison and co-ordination across Government agencies in co-operation with local Aboriginal communities;

- The establishment of an Aboriginal Affairs Department structured as a planning, advisory, coordinating and monitoring agency and not responsible for administration of specific programmes.

In order to implement these recommendations the Government established AAD. AAD has utilised the virtual organisation planning model (figure 4) and established the Aboriginal Affairs Co-ordinating Committee (AACC).

The AACC consists of Chief Executive Officers from all State Government agencies that have a role in Aboriginal affairs including education, justice, police and housing. The major role of the AACC is to establish a set of strategic goals for Aboriginal affairs and to ensure that each of their agencies implement processes aimed at achieving the goals.

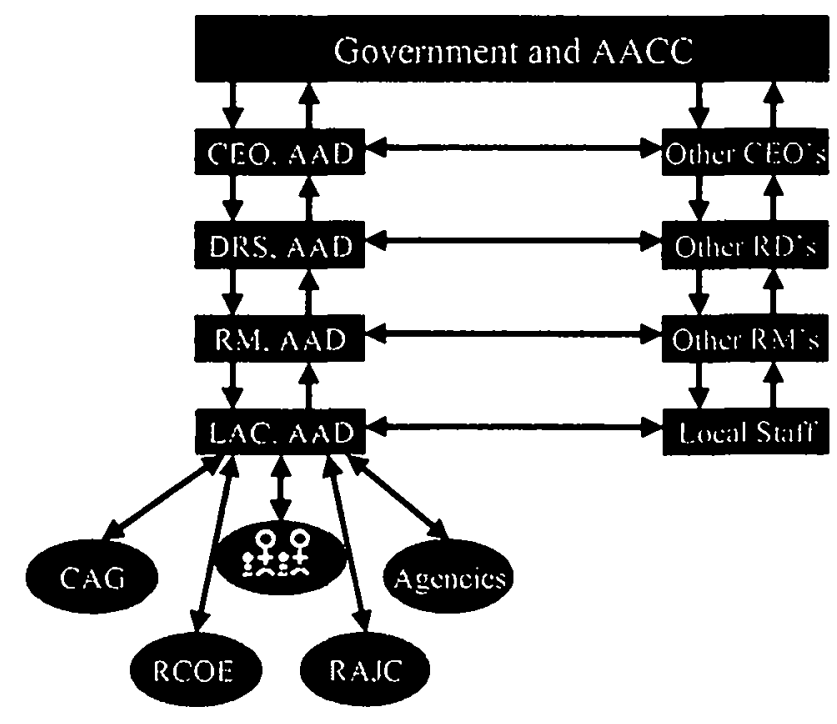

Figure 4 - Aboriginal Affairs Virtual Organisation

Within AAD a structure known as a local area co-ordination approach (LAC) has been established to ensure: 
- Pervasive knowledge sharing, feedback and communication;

- Integration of environmental considerations at the earliest stages of design;

- Effective partnerships with customers.

- Commitment to using customer feedback to drive changes in operations, goals and vision; and

- Frontline employees are given the authority to deal with customer issues.

This overall structure was implemented in the $\mathrm{AAD}$ and evaluated through interviews and on-site assessments by the authors over a period of one year. One of the authors then had the opportunity to participate as manager of a specific customer-centric project and this is discussed below.

\section{The Aboriginal Heritage Land Management System}

The $\mathrm{AAD}$ is responsible for the implementation of the Aboriginal Heritage Management Act which states that all Aboriginal Sites in W.A. be recorded and that prior to any development a search of sites must be conducted to determine the impact of development on sites in the area. It should be noted that these sites may not be inhabited but traditionally have strong spiritual significance for the Aboriginal community and non-Aboriginals and indeed Aboriginals from different tribes outside this community would normally not be permitted access to these sites. For this reason much secrecy often surrounds the location of these sites. If sites are to be impacted then the developer must consult with the site custodians (typically through the Regional Commission of Elders (RCE)) and apply to the Minister for Aboriginal Affairs to either destroy or move the site depending on the nature of the site and the type of development.

As described previously, AAD has a history of each division working separately with very little interaction between divisions or branches. Originally the Heritage and Culture Division (HCD) had full responsibility for all aspects of Aboriginal sites. The Division was strongly opposed to providing information on these sites to mining companies and land developers as they believed this was the most appropriate way of protecting sites. One manager openly labelled mining companies and some Government agencies as "red necks" and was strongly opposed to forming alliances with these organisations and sharing information.

Following the restructure of the $\mathrm{AAD}$ the management of the information component of Aboriginal sites was moved to the Information Management Division (IMD). This prompted the evaluation of the current status of the sites register and the development of a project to completely revamp all aspects of the system. This necessitated not only close cooperation between the two divisions but the development of a network of agencies and an extension of these to an enhanced value network (EVN).

Organisations that formed part of the network include:

- AAD - IMD (ICT, GIS, Data Management), HCD (Archaeology, Anthropology)

- State Agencies - Main Roads W.A., Department of Conservation and Land Management, Waters and Rivers Commission, Department of Resources Development, Department of Minerals and Energy

- Commonwealth Agencies - National Native Land Tribunal, Indigenous Land Corporation, Department of Defense, CSIRO

- Other Agencies - Aboriginal legal Services, Goldfields Land Council, Wesfarmers, AWI Administration Services. Shire of Busselton, ACMC

These Agencies all had different standards and procedures and often competed for budgets and authority. Two main Customer Groups were identified (other groups include consultants and researchers):

- Aboriginal Communities

- Mining and Resource Development Companies - Robe River Mining, Alcoa, Western Mining, BHP Iron Ore, Acacia Resources, Packman Mining, Normandy Mining

Both groups required accuracy of information about location of sites and also cultural heritage and use of sites. However, Aboriginal people required protection of information about closed sites while developers needed to know where these were in order to avoid them. Many longstanding issues of political, cultural and economic tensions served to make collaboration a less then easy task. Nevertheless, compromises were reached, one example being where boxes which masked the exact location of closed sites were reduced from 100 square kilometres to four and sites would be designated closed only at the request of Aboriginal people. Full paper based files on these would be designated "Red Files" to prevent unauthorised access. 


\section{The System}

The GIS was designed as a web-based application using Internet technology. The database is linked to maps of the site locations and boundaries and access comes via the database. Clients often assign their own site references and these are cross-indexed with the AAD references to allow searching by client reference number. Access is only available to organisations who have signed a licensing agreement in accordance with the endorsed policies, and access automatically ceases on expiry of the agreement. Customers will be provided with site maps within the constraints implemented for preservation of closed sites.

The new system streamlines site registration and site searches resulting in significant reductions in turnround time from six to ten weeks to two to three minutes and provides much greater accuracy. Companies can also download mapping and site index data into their own systems with monthly updates. The library catalogue allows for a variety of different reports accessible to the public. For example, a consultant can specify a mining tenement of interest and all heritage survey reports within this area can be identified

By streamlining site registration and searches, improving the relevance and accuracy of stored data, and making the information more accessible the new system has had a positive impact on the whole enhanced value network.

\section{LESSONS LEARNED}

\section{Customer-Centric Model of AAD}

The primary aim of the restructured $A A D$ is to ensure that all Government services revolve around its customers as opposed to establishing bureaucracies that customers need to break into to obtain the services they require. That is to establish a mechanism that will:

- Assist AAD's customers receive equitable services from Government agencies;

- Inform Government of unmet needs and priority issues; and

- Facilitate co-ordination of services across agencies.

To achieve this the Department has looked at ways to best share resources, skills and knowledge to provide better access to a wide range of Government services for their clients. This fits with the developing model of $e-$ Government (Table 2) as follows:

\begin{tabular}{|c|c|c|c|}
\hline & The Agency & $\begin{array}{l}\text { Network of Agencies } \\
\text { B2B }\end{array}$ & $\begin{array}{l}\text { Enhanced Value Network } \\
\text { e-Government }\end{array}$ \\
\hline $\begin{array}{l}\text { Unit of } \\
\text { analysis }\end{array}$ & $\begin{array}{l}\text { AAD: } \\
\text { IMD } \\
\text { HCD }\end{array}$ & $\begin{array}{l}\text { State, } \\
\text { Commonwealth and } \\
\text { Other Agencies }\end{array}$ & $\begin{array}{l}\text { Aboriginal Communities } \\
\text { Mining and Resource } \\
\text { Development }\end{array}$ \\
\hline Resources & $\begin{array}{l}\text { ITC } \\
\text { Heritage } \\
\text { knowledge }\end{array}$ & $\begin{array}{l}\text { Legal } \\
\text { Land Use } \\
\text { Statutory } \\
\text { Research }\end{array}$ & $\begin{array}{l}\text { Development plans } \\
\text { Mineral Sources } \\
\text { Closed and Open sites } \\
\text { Tradition and Customs }\end{array}$ \\
\hline $\begin{array}{l}\text { Basis for } \\
\text { access to } \\
\text { competence }\end{array}$ & $\begin{array}{l}\text { AAD } \\
\text { specific } \\
\text { processes }\end{array}$ & $\begin{array}{l}\text { Privileged access to } \\
\text { system for all } \\
\text { agencies within the } \\
\text { network }\end{array}$ & $\begin{array}{l}\text { Secure Authorised access for } \\
\text { Searching and Updating } \\
\text { Accurate site info } \\
\text { Preservation of culture }\end{array}$ \\
\hline $\begin{array}{l}\text { Added } \\
\text { Value of } \\
\text { managers }\end{array}$ & $\begin{array}{l}\text { Nurture and } \\
\text { build cross } \\
\text { Divisional } \\
\text { (virtual) } \\
\text { teams }\end{array}$ & $\begin{array}{l}\text { Manage multiple, } \\
\text { complex and } \\
\text { conflicting Agency } \\
\text { relationships }\end{array}$ & $\begin{array}{l}\text { Harmess Aboriginal knowledge } \\
\text { and culture } \\
\text { Manage land exploitation and } \\
\text { development more effectively }\end{array}$ \\
\hline $\begin{array}{l}\text { Value } \\
\text { creation }\end{array}$ & Autonomous & $\begin{array}{l}\text { For all partner } \\
\text { agencies }\end{array}$ & $\begin{array}{l}\text { For both Aboriginals and } \\
\text { developers }\end{array}$ \\
\hline $\begin{array}{l}\text { Sources of } \\
\text { managerial } \\
\text { tension }\end{array}$ & $\begin{array}{l}\text { Divisional } \\
\text { autonomies } \\
\text { and different } \\
\text { core } \\
\text { competencies }\end{array}$ & $\begin{array}{l}\text { Agencies' different } \\
\text { regulations and } \\
\text { conflicting purposes }\end{array}$ & $\begin{array}{l}\text { Aboriginal customs } \\
\text { (Preservation) } \\
\text { Corporate development plans } \\
\text { (Exploitation) }\end{array}$ \\
\hline
\end{tabular}

Table 2: Customer Value Alliance Model of Heritage Management System 
That is each partner in the value alliance :

- brings its core competence - Aboriginal Affairs Department is not required to have expertise in areas such as Education, Health, Housing or Justice;

- has access to other competencies and customer life cycles;

- develops flexible collaborative partnerships - the amount of involvement each agency has in each of the goals varies depending on the agency's specific skills and over time the amount of involvement will change as progress is made towards achieving the goals;

- trusts and is trusted - for this co-alliance to be successful mutual cooperation will need to develop. This has started to develop through the coordinating committee. All Chief Executive Officers have participated in the meetings and not sent a representative, and agreement has been reached on the primary goals. It remains to be seen if this mutual cooperation does flow down through each Agency. The Local Area Coordinators are working with their local counterparts on common goals however sections of each Agency's central office are yet to develop mutual cooperation;

- establishes appropriate communication links where all stakeholders have evidence of information flowing up and down the model;

- must see immediate benefits and be able to impact on the goal setting process - this is particularly important for clients and the LACs are pivotal to this process and must be recruited with care.

\section{Value Alliance Model of Heritage System}

For this alliance to work, trust was the most important factor. AAD took the first step towards this by reversing the policy that "protection means exclusion to information" and allowed their information to be vulnerable. This vulnerability of one party to another was a crucial concept that had to be seen to be shared by all players to ensure collaboration. (Mayer et al, 1995). Protection was defined as disclosure of information and developers were portrayed as organisations who inherently wanted to do the "right thing", adhere to legislative requirements and assist with protection of sites. Trust was engendered in the Aboriginal communities by ensuring they had input to all policies and procedures and that they were regarded as the senior decision makers to any changes in these.

The second success factor came from the decision made from the outset to centralise the approach and establish a steering committee representative of all stakeholders to oversee the knowledge gathering and management. This committee was charged with the coordination of internal and external networks as well as the effective use of resources to ensure a positive outcome for the project. The processes that were followed matched closely the guidelines proposed by Berry and Parasuraman (1997) for developing an effective service-quality information system:

1. Measure service expectations

2. Emphasise information quality

3. Capture customer words

4. Link service performance to business results

5. Reach every employee.

Throughout the project and beyond implementation customer satisfaction surveys were conducted, stakeholder groups were interviewed, the Steering Committee formed a customer advisory panel and all processes were constantly evaluated and altered as necessary.

The perceived success of the system was based on technical achievement (the old system was paper-based and had remained unchanged for 15 years) but more importantly on the successful collaboration with a number of diverse players. The building block approach assisted this greatly since the $A A D$ had previously restructured its Agency and established inter-agency collaboration around customer services. This meant that in the development of this particular system priority could be given to building the enhanced value network through the customers with appropriate inter-agency communication channels already established. The LACs assumed the most important role of customer interface and support with full authority and support from the agency network.

\section{CONCLUSION}

As a study in progress the establishment of this model is in its infancy. It is currently too early to tell what impact this model has had on the goals AAD have set out to achieve nor the effect it has had on the Department's primary client base - Aboriginal people. Further research is required as AAD further implements its LAC model and establishes appropriate communication procedures. The authors are also now evaluating this model in the context of two different Government Agencies who are attempting to implement customer-centric, e-government systems. 
There is much research left on the subject of the implementation of the value alliance model in a government agency, especially with regard to the distribution of information and communication. Managing a virtual organisation may require a whole new set of virtual information leadership skills (Morin et al, 2000). Storing knowledge and expertise from both partners and customers are also important areas of consideration.

\section{REFERENCES}

Barreyre, P. Y. (1988). “The concept of 'impartition' policies: a different approach to vertical integration strategies." Strategic Management Journal 9: 507-520.

Burn, J. M. and Hackney, R. (2000) Strategies for I-Business Change in Virtual Markets: a co-evolutionary approach. International Journal of e-Business Strategy Management, Vol, 2, No. 2, 123-133.

Burn, J. M. and Barnett, M. L. (2000) Emerging Virtual Models for Global e-commerce - world wide retailing in the e-grocery business. Special issue on Global E-Commerce, Special Millennium Issue of Journal of Global Information Technology Management, Vol 3, No. 1, pp 18-32.

Campbell, A. and P. DiNicola (1997). "Virtual Organisations. Problem setting and research agenda.".

Cavanagh, J. J. and D. J. Livingston (1997). Serving The American Public: Best Practices in Customer-Driven Strategic Planning.

El Sawy, O. A., Malhotra, A., Gosain, S. Young, K. M. "IT-Intensive Value Innovation in the Electronic Economy: Insights from Marshall Industries," MIS Quarterly, (32:3), 1999, pp. 305-335.

Glassey, O. (2001). Model and Architecture for Virtual One-Stop Public Administration. 9th European Conference on Information Systems, Bled, $969-977$.

Hopkins, C. and J. K. Jamil (1997). Serving the American Public - Best Practices in One-Stop Customer Service., Federal Benchmarking Consortium.

Jellinek, D. (2000).E-Government - - Reality or Hype? E-Government Bulletin, October. Avaialble at http://www.cisp.org/imp/october_2000/10_00jellinek.htm

Miles, R. E. and C. C. Snow (1995). "The new network firm: A spherical structure built on a human investment philosophy." Organizational Dynamics 23 (4): 4-18.

Morin, T. Devansky, K. Little, G. and Petrum, C. (2000). The Future of Information Leadership. In Information leadership - A Government Executive's Guide, PricewaterhouseCoopers Publications.

Prahalad, C. K. and V. Ramaswamy (2000). Co-opting customer competence. Harvard Business Review 78(1)(79-87).

Schoeniger, E. (2000). The Future of Electronic Government. Unisys Exec, Sep-Oct, 2000, 8-14.

Sprecher, M. H. (2000) Racing to e-government: Using the Internet for citizen service delivery. Government Finance Review, Vol. 16, 5, 21-22.

Stamoulis, D. S., Gouscos, D., Georgiadis, P. and Martakos, D. (2001). Re-Orienting Information Systems for Customer-Centric Service. The Case of the Greek Ministry of Finance. 9th European Conference on Information Systems, Bled, 977-986.

Stratford, J. S. and Stratford, J. (2000). Computerised and Networked Government Information. Journal of Government Information, 27, 385-389.

Symonds, M. (2000). Government and the Internet: The Next Revolution. The Economist, Jun 24.

Ticoll, D., Lowry, A. and Kalakota, R. (1998) Joined at the Bit, in Blueprint to the Digital Economy creating wealth in the era of e-business Don Tapscott, Alex Lowy and David Ticoll, McGraw-Hill

Traunmuller, R. (2001). Relevance of Portals in e-Government. 14th Bled Electronic Commerce Conference, $35-45$.

Von Hoffman, C. (1999). The Making of E-Government. COI Enterprise Magazine, Nov, 15.

Zulfiker, K. A., Pan, S, L., Lee, J. N. and Huang, J. C. (2001) E-Government: An Exploratory Study of On-Line Electronic Procurement Systems. 9th European Conference on Information Systems, Bled, 1010-1022. 